\title{
The Relationship Between Postmenopausal Osteoporosis and Autophagic Gene Polymorphisms
}

\author{
Postmenopozal Osteoporoz ve Otofajik Gen Polimorfizmleri Arasındaki illişki
}

\author{
(D) Türkan Turgay, (D) Elif Pala*, (D) Filiz Özbaş Gerçeker**, (D) Savaş Gürsoy***, (D) Özlem Altındağ***, (D) Ali Aydeniz*** \\ SANKO University, Sani Konukoğlu Practice and Research Hospital, Clinic of Physical Medicine and Rehabilitation, Gaziantep, Turkey \\ *SANKO University Faculty of Medicine, Department of Medical Biology, Gaziantep, Turkey \\ **Gaziantep University Faculty of Arts and Science, Department of Biology, Division of Molecular Biology, Gaziantep, Turkey \\ ***Gaziantep University Faculty of Medicine, Department of Physical Medicine and Rehabilitation, Gaziantep, Turkey
}

\section{Abstract}

Objective: This study investigates the role of ATG16L1 rs2241880, ATG10 rs1864183 and ATG5 rs2245214 gene polymorphisms, which are involved in autophagosome formation, in the susceptibility to postmenopausal osteoporosis (PMO) disease.

Materials and Methods: Hundred PMO patients and 100 healthy controls without PMO were included into the study. The distribution of the genotypes of ATG16L1 rs2241880, ATG10 rs1864183 and ATG5 rs2245214 polymorphisms in these subjects were analyzed using the TaqMan 5 '-exonuclease allelic discrimination assay.

Results: The T allele was detected more frequent among patients with osteoporosis (53\%) of the ATG10 rs1864183 polymorphism. C allele in ATG16L 1 rs 2241880 polymorphism in the group of patients with osteoporosis was observed more frequent (56.5\%). Besides, the G allele of the ATG5 rs2245214 polymorphism was identified more common in PMO (34\%) than in control group. However, no significant difference were detected in genotype and allele frequencies in terms of these polymorphisms between the patient and the control groups ( $p>0.05$ ). Conclusion: In summary, the results of our study do not support the hypothesis that ATG16L1 rs2241880, ATG10 rs1864183 and ATG5 rs2245214 polymorphisms influence the predisposition for osteoporosis in postmenopausal women.

Keywords: Autophagy, gene polymorphism, postmenopausal osteoporosis

\section{Öz}

Amaç: Bu çalışmada otofajik mekanizmada otofagozom oluşumunda yer alan ATG16L 1 rs2241880, ATG10 rs1864183 ve ATG5 rs2245214 gen polimorfizmlerinin postmenopozal osteoporoz (PMO) hastalığına yatkınlıktaki rolü incelenmiştir.

Gereç ve Yöntem: Bu çalışmaya 50 yaş ve üzeri PMO'su olan 100 hasta ve PMO gelişimi olmayan 100 kontrol grubu alınmıştır. ATG16L1 rs2241880, ATG10 rs1864183 ve ATG5 rs2245214 polimorfizmlerinin genotiplendirmesi amacıyla polimorfik dizileri çoğaltmak için diziye özgü primerler ve her polimorfizmin her iki alelini saptamak için TaqMan 5 '-ekzonükleaz alelik diskriminasyon yöntemi kullanılmıştır.

Bulgular: ATG10 rs1864183 polimorfizminin osteoporozlu (\%53) hastalarda T aleli daha sık saptanmıştır. Osteoporozlu hasta grubunda ATG16L1 rs2241880 polimorfizmindeki C aleli daha sık görülmüştür (\%56,5). Ayrıca, ATG5 rs2245214 polimorfizminin G aleli, PMO'da (\%34) kontrol grubuna göre daha yüksek olarak tanımlanmışır. Ancak genotip ve alel frekanslarında hasta ve kontrol grupları arasındaki bu polimorfizmler açısından anlamlı fark saptanmamıştır $(p>0,05)$.

Sonuç: Özetle, çalışmamızdaki sonuçlar ATG16L1 rs2241880, ATG10 rs1864183 ve ATG5 rs2245214 polimorfizmlerinin postmenopozal kadınlarda osteoporoza yatkınlık sağlayabileceği hipotezini desteklememektedir.

Anahtar kelimeler: Gen polimorfizmi, postmenopozal osteoporoz, otofaji 


\section{Introduction}

According to the World Health Organization, Osteoporosis is a systemic skeletal disease that is characterized by low bone mass, decreased bone strength, leading to increased microarchitectural structure and quality of bone tissue together with an increase in the risk of fractures (1). Osteoporosis is a metabolic bone disease that causes an important public health problem in terms of the incidence of osteoporosis fractures associated with morbidity and mortality with the increase of the aging population in our country as well as all over the world (2). The disease progresses silently until a secondary disease like cardiovascular disease or fractures resulting in mortality (3). In the FRACTURK study, which examined the epidemiology of osteoporosis in Turkey in recent years, the prevalence of osteoporosis in the femoral neck was determined to be $7.5 \%$ in men over the age of 50 , while the women was $33.3 \%$ (4). Hip fractures are the ones that have the highest economic burden and are mortal among other osteoporotic fractures. In the Turkish population, the probability of hip fracture in individuals aged 50 and over is 3.5\% in men and $14.6 \%$ in women for the rest of their life (5).

Osteoporosis is a multifactorial disease that is affected by genetic, hormonal, nutritional factors and lifestyle $(6,7)$. Peak bone mass is reached in adult life, and both men and women begin to lose more or less bone mass at this point depending on the combination of internal and external factors $(8,9)$. This process can become worse with the presence of other chronic diseases like immobilization (10), long-term corticosteroid therapy (11), estrogen deficiency (12), aging (13) and diabetes, especially for postmenopausal women.

Although estrogen deficiency in postmenopausal women is considered to be the main reason for bone loss and osteoporosis, studies showed that it is one of the most important factors contributing to bone loss caused by aging and increased oxidative stress in bone tissue $(14,15)$.

Autophagy is a catabolic process that degradation of the cellular content occurs lysomally, which is stored by a double membrane vesicle called autophagosome; thus, cells maintain homeostatic functions such as protein breakdown and organelle turnover process. Under physiological conditions, although autophagy is responsible for the removal of damaged or unnecessary organelles, under pathological conditions, it helps to redistribute the intracellular nutrients to cover the energy requirement. In this way, it controls the energy and chemical homeostasis of each cell and various types of tissues, including bones (16). Recent studies have shown that autophagy plays an important role in remodelling and differentiation of the stem cells, so that the relation between autophagy and bone metabolic disease pathogenesis has attracted a lot of interest (17).

In the literature, studies on the relation between autophagyrelated gene (ATG) polymorphisms and osteoporosis are very limited. In this study, our purpose was to examine the effect of polymorphisms in genes involved in the formation of autophagosome in the autophagic mechanism on the risk of developing postmenopausal osteoporosis (PMO). In this context, the role of ATG16L1 rs2241880, ATG10 rs1864183 and ATG5 rs2245214 gene polymorphisms in the susceptibility to PMO disease was investigated.

\section{Materials and Methods}

\section{Subjects}

A hundred postmenopausal osteoporosis patients aged 50 years and over, and 100 control individuals without the development of postmenopausal osteoporosis, who referred to SANKO University, Sani Konukoğlu Practice and Research Hospital, Clinic of Physical Medicine and Rehabilitation in the last 1 year, were included in the study. Individuals who had early menopause, malabsorption, major gastrointestinal operation, metabolic bone diseases, hyper and hypothyroidism, hormone replacement therapy, and also, individuals using antiosteoporosis and active vitamin D3 medications that could affect bone and calcium metabolism were excluded from the study.

The risk assessment of the participants for fracture risks was examined with the dual energy X-ray absorptiometry device (GELunar DPX) and standard protocol was used as bone mineral density (BMD) $\left(\mathrm{g} / \mathrm{cm}^{2}\right)$ in the femur neck and lumbar spinal area (18). SANKO University Clinical Research Ethics Committee of approved the study protocol (decision no: 05, date: 24.07.2018). Informed consents were obtained from all participants.

\section{DNA Isolation and Polymorphism Genotyping}

Genomic DNA was extracted from 5 peripheral blood samples of 200 individuals according to the protocol recommended by the manufacturer. Genotypings of ATG2B rs3759601, ATG16L1 rs2241880, ATG10 rs1864183 and ATG5 rs2245214 polymorphisms were performed using TaqMan 5 '-exonuclease allelic discrimination assays that contain sequence-specific forward and reverse primers to amplify the polymorphic sequences and two probes labeled with VIC and FAM dyes to detect both alleles of each polymorphism (19). Polymerase chain reaction $(P C R)$ reactions were carried out using TaqMan universal PCR Master Mix following instructions in a Step-One Plus Real-time PCR system. In the application of this method, Real-time PCR device in the Department of Biology of Gaziantep University Faculty of Science was used. The autophagic gene polymorphisms and locations that were examined are given in Table 1.

\begin{tabular}{|c|c|c|c|c|}
\hline SNP & SNP ID & $\begin{array}{l}\text { Base } \\
\text { change }\end{array}$ & SNP & $\begin{array}{l}\text { Chromosomal } \\
\text { location }\end{array}$ \\
\hline ATG $16 L 1$ & rs2241880 & $\mathrm{T}>\mathrm{C}$ & T300A & 2 \\
\hline ATG10 & rs1864183 & $C>T$ & T212M & 5 \\
\hline ATG5 & rs2245214 & $C>G$ & Intronic & 10 \\
\hline
\end{tabular}




\section{Statistical Analysis}

Statistical analysis was made using IBM SPSS Statistics for Windows, Version 23.0 (IBM Corp., Armonk, NY). Categorical data were analyzed by Pearson chi-square test and Fisher's exact test. The normality assumptions were controlled by the Shapiro-Wilk test. The differences between the two groups were evaluated with Student's t-test for normally distributed data, or with Mann-Whitney $U$ test for non-normally distributed data. Data are expressed as $n(\%)$, mean \pm standard deviation (range) or median (range), as appropriate. $P$ values $<0.05$ were considered statistically significant.

\section{Results}

\section{Demographic Characteristics and Bone Mineral Density Status of Participants}

The baseline characteristics of the study population are presented in Table 2. As expected, the body mass index, BMD values of

\begin{tabular}{|c|c|c|}
\hline & $\begin{array}{l}\text { Control } \\
(n=100)\end{array}$ & $\begin{array}{l}\text { Patients } \\
(n=100)\end{array}$ \\
\hline Age & $\begin{array}{l}61.08 \pm 7.13 \\
(50-76)\end{array}$ & $\begin{array}{l}64.62 \pm 7.16 \\
(50-78)^{*}\end{array}$ \\
\hline BMI & $\begin{array}{l}32.46 \\
(21.94-346.81)\end{array}$ & $\begin{array}{l}28.5 \\
(17.75-41.12)^{*}\end{array}$ \\
\hline \multicolumn{3}{|c|}{ Habitual smoking } \\
\hline Yes & $5(8.8)$ & $14(14.1)$ \\
\hline No & $52(91.2)$ & 85 (85.9) \\
\hline Total L1-L4 & $-0.4(-2.3-2.9)$ & $-2.5(-4.7-0.5)^{\star}$ \\
\hline Total L2-14T & $-0.4(-2.3-3.6)$ & $-2.5(-5.1-3.2)^{\star}$ \\
\hline Total femur $\mathrm{T}$ & $-0.2(-2.4-2.8)$ & $-1.75(-6.9-0.7)^{*}$ \\
\hline Total neck T & $-0.7(-2.3-10)$ & $-1.8(-5-2)^{*}$ \\
\hline \multicolumn{3}{|c|}{ Presence of fractures } \\
\hline Yes & $6(11.5)$ & $37(38.9)^{*}$ \\
\hline No & $46(88.5)$ & $58(61.1)$ \\
\hline \multicolumn{3}{|c|}{$\begin{array}{l}\text { Data are presented as } \mathrm{n}(\%) \text {, mean } \pm \text { standard deviation (range), median } \\
\text { (range). *Significant p-values are represented } \\
\text { BMI: Body mass index }\end{array}$} \\
\hline
\end{tabular}

the lumbar spine (L1-L4), femoral neck and total hip showed significant differences between patient and control groups.

\section{ATG10, ATG16L1 and ATG5 Genotypes and Allele Distributions}

The genotypic frequencies and the result of the association analysis of ATG10 rs1864183, ATG16L1 rs2241880 and ATG5 rs2245214 polymorphisms in $\mathrm{PMO}$ and controls are summarized in Table 3. The distribution of allelic frequencies for ATG10, ATG $16 L 1$ and ATG5 polymorphisms are shown in Table 4.

The $T$ allele of the ATG10 polymorphism was more common among patients with osteoporosis (53\%) than in normal controls (51\%). C allele in ATG16L1 rs2241880 polymorphism in the group of patients with osteoporosis was observed more frequent $(56.5 \%)$ than in control group (55\%). Besides, the $\mathrm{G}$ allele of the ATG5 rs2245214 polymorphism was identified more common in PMO (34\%) than in control group (29.5\%). However, no significant difference was detected in genotype and allele frequencies in terms of these polymorphisms between the patient and control groups ( $p>0.05$ ) (Table 4).

Moreover, among the studied groups, the effect of autophagy gene polymorphisms on the risk of developing PMO was

\begin{tabular}{|c|c|c|c|}
\hline & Control & Patients & $p$ \\
\hline \multicolumn{4}{|c|}{ ATG5 } \\
\hline CC & $42(42 \%)$ & $48(48 \%)$ & 0.599 \\
\hline CG & $48(48 \%)$ & $45(45) \%$ & - \\
\hline GG & $10(10 \%)$ & $7(7 \%)$ & - \\
\hline \multicolumn{4}{|c|}{ ATG10 } \\
\hline CC & $23(23 \%)$ & $25(25 \%)$ & 0.926 \\
\hline $\mathrm{CT}$ & $48(48 \%)$ & 48 (48\%) & - \\
\hline TT & $29(29 \%)$ & 27 (27\%) & - \\
\hline \multicolumn{4}{|c|}{ ATG16L1 } \\
\hline TT & $22(22 \%)$ & $20(20 \%)$ & 0.604 \\
\hline TC & $43(43 \%)$ & $50(50 \%)$ & - \\
\hline CC & 35 (35\%) & $30(30 \%)$ & - \\
\hline
\end{tabular}

Table 4. Allele frequencies of autophagy gene polymorphisms among cases and controls and the association with postmenopausal osteoporosis

\begin{tabular}{|c|c|c|c|c|}
\hline SNP & Allele & Patients & Controls & $p$ \\
\hline \multirow{2}{*}{ ATG10 rs1864183 } & C & $94(47 \%)$ & $98(49 \%)$ & \multirow{2}{*}{0.764} \\
\hline & $T$ & $106(53 \%)$ & $102(51 \%)$ & \\
\hline \multirow{2}{*}{ ATG16L 1 rs2241880 } & $T$ & $87(43.5 \%)$ & $90(45 \%)$ & \multirow{2}{*}{0.840} \\
\hline & C & $113(56.5 \%)$ & $110(55 \%)$ & \\
\hline \multirow{2}{*}{ ATG5 rs2245214 } & C & $132(66 \%)$ & $141(70.5 \%)$ & \multirow{2}{*}{0.390} \\
\hline & G & $68(34 \%)$ & 59 (29.5\%) & \\
\hline
\end{tabular}


evaluated and correlated with bone parameters. No significant differences were found in the analysis of the different clinical forms and the genotypic distributions of the polymorphisms included in our study.

\section{Discussion}

Autophagy is a catabolic process that is responsible for the fragmentation and recycling of cellular components like unnecessary organelles and proteins. The process begins with the formation of "autophagosome" merged with lysosomes and hydrolase that is responsible for disrupting the content of the target $(20,21)$. At least 18 ATG genes (related to autophagy) were identified in the formation of autophagosome (22). It was shown in recent years that proteins that are involved in bone destruction and construction of autophagy play important roles in regulating osteoclastogenesis $(23,24)$ but the effect of autophagic genes in osteoporosis is not yet unexplained completely. It has also been shown that autophagy plays critical roles in the onset and progression of pathological conditions that are characterized by many metabolic disorders, including both physiological process and metabolic disease (25), cancer (26), neurodegenerative diseases (27), aging (28) and bonerelated diseases (29).

In vitro studies demonstrated that autophagy increases oxidative stress in osteoblast-like cells and stimulates apoptosis in these cells with pharmacological inhibition of autophagy (30). Unlike this, in osteoblast-like cell cultures, the induction of autophagy reduces oxidative stress and inhibits apoptosis (31). It was reported that estrogen inhibits osteoblast apoptosis in vitro and induces autophagy in these cells (32).

Studies revealed that autophagy plays an important role in osteoclast-mediated bone resorption. Gene deletions (ATG5, ATG7, $A T G 4 B$ and LC3) that encode key proteins in the formation of autophagosome reduced bone resorption and increased bone volume in mice after ovariectomy (in the osteoclast brush border) $(33,34)$. Some authors suggested that autophagy inhibition in osteoclasts might serve as a possible therapeutic mechanism against bone diseases, which means an excessive increase in bone resorption. It was observed that pharmacological and genetic inhibition of autophagy prevented bone loss in mice caused by ovariectomy or glucocorticoid treatment, reducing osteoclast genesis and bone resorption (35).

Aging is among the most closely related factors with the onset of osteoporosis with the changes in hormones and increased oxidative stress (36). Parallel to this, the autophagic activity level in many cells decreases during aging, more pronounced in osteocytes and osteoclasts. This hypothesis was supported by studies conducted on many animal models $(37,38)$.

It was shown in previous studies that autophagy modulation has therapeutic potential in the prevention and treatment of bone-related diseases. However, the modulation of autophagic activity may not be enough alone to affect the overall remodeling process of the skeletal system. And, larger and randomized controlled clinical studies are needed to be conducted on humans to validate the possible relation between autophagic dysfunction and osteoporosis and develop potential pharmacological treatments for bone diseases.

In the literature, there are several studies in which ATG16L 1 was investigated for the effect of polymorphism on the predisposition to autoimmune diseases, and it was found that Crohn's disease, ulcerative colitis, palmoplantar pustulosis play roles in this respect (39-41). High ATG5 levels were detected in autoimmune demyelination and multiple sclerosis in mice model and humans (42), ATG expression in synovial tissue, between disease activity and severity in patients with active rheumatoid arthritis relations were found to be significant (43).

In another study, it was reported that GC genotype has protective effects on the development of small-cell lung cancer in ATG5 rs2245214 gene polymorphism (44). In a study that was conducted in Spain a relation was detected between ATG10 rs1864183 and laryngeal cancer, ATG16L 1 rs241880 and oral carcinoma development. Also, in Spain, a study examined the effects of the same autophagic gene polymorphism in Paget's disease, which is the most common metabolic bone disease after osteoporosis. It was shown that carrying ATG16L1 rs2241880 and ATG5 rs2245214 polymorphisms were associated with increased risk of developing Paget's disease, and ATG10 rs1864183 polymorphism was associated with increased Paget's disease risk, and carrying T allele of ATG10 rs1864183 polymorphism was associated with reduced risk (45).

This study is the first that examined ATG16L $1 \mathrm{rs} 2241880$, ATG10 rs1864183 and ATG5 rs245214 gene polymorphisms in PMO women. No significant relations were detected between PMO patients and control groups in terms of these polymorphisms. As a result, the data of this study showed that the polymorphisms might not contribute to the predisposition of PMO. A future study is planned to be conducted in different populations and larger sampling sizes.

\section{Acknowledgments}

We thank Oğuz Akveç for his technical support.

\section{Ethics}

Ethics Committee Approval: SANKO University Clinical Research Ethics Committee of approved the study protocol (decision no: 05, date: 24.07.2018).

Informed Consent: Informed consents were obtained from all paticipants.

Peer-review: Externally peer-reviewed.

\section{Authorship Contributions}

Surgical and Medical Practices: T.T., S.G., Ö.A., A.A., Concept: T.T., E.P., F.Ö.G., Design: E.P., F.Ö.G., Data Collection or Processing: T.T., E.P., Analysis or Interpretation: E.P., Literature Search: T.T., E.P., Writing: T.T., E.P., F.Ö.G.

Conflict of Interest: No conflict of interest was declared by the authors. 
Financial Disclosure: Overall funding was provided by a Research Project Grant (No: FEF.19.09) through the Gaziantep University Scientific Research Projects Coordination Unit.

\section{References}

1. Kanis JA, Melton LJ, Christiansen C, Johnston CC, Khaltaev N The diagnosis of osteoporosis. J Bone Miner Res 1994:1137-41.

2. Hepgüler S, Cetin A, Değer C, Erkent U. Acta Orthop Traumatol Turc. Osteoporotic hip fracture costs in the elderly Turkish population 2011:45:316-25.

3. Farhat GN, Cauley JA. The link between osteoporosis and cardiovascular disease. Clin Cases Miner Bone Metab 2008;5:1934.

4. Tuzun S, Eskiyurt N, Akarirmak U, Saridogan M, Johansson H, McCloskey $E$, et al. The impact of a FRAX-based intervention threshold in Turkey: the FRAX-TURK study. Arch Osteoporos 2012;7:229-35

5. Tuzun S, Eskiyurt N, Akarirmak U, Saridogan M, Senocak M, Johansson $\mathrm{H}$, et al. Incidence of hip fracture and prevalence of osteoporosis in Turkey: the FRACTURK study. Osteoporos Int 2012;23:949-55

6. Tella SH, Gallagher JC. Prevention and treatment of postmenopausal osteoporosis. J Steroid Biochem Mol Biol 2014;142:155-70.

7. Klein-Nulend J, van Oers RF, Bakker AD, Bacabac RG. Bone cell mechanosensitivity, estrogen deficiency, and osteoporosis. J Biomech 2015;48:855-65.

8. Raisz L, Seeman E. Causes of age related bone loss and bone fragility: an alternative view. J Bone Miner Res 2001:16:1948-52.

9. Demontiero O, Vidal C, Duque G. Aging and bone loss: new insights for the clinician. Ther Adv Musculoskelet Dis 2012;4:6176.

10. Hamrick I, Schrager S, Nye AM. Treatment of osteoporosis: current state of the art. Wien Med Wochenschr 2015;165:54-64

11. Whittier X, Saag KG. Glucocorticoid-induced osteoporosis. Rheum Dis Clin North Am 2016;42:177-89.

12. Khosla S, Oursler MJ, Monroe DG. Estrogen and the skeleton. Trends Endocrinol Metab 2012:23:576-81.

13. Lunt M, Masaryk P, Nave CS, Nijs J, Poor G, Pols G, et al. The effects of lifestyle, dietary dairy intake, and diabetes bone density and vertebral deformity prevalance: The EVOS study. Osteoporos Int 2001;12:688-98.

14. Chen K, Yang YH, Jiang SD, Jiang LS. Decreased activity of osteocyte autophagy with aging may contribute to the bone loss in senile population. Histochem Cell Biol 2014;142:285-95.

15. Almeida M, O'Brien CA. Basic biology of skeletal aging: role of stress response pathways. J Gerontol A Biol Sci Med Sci 2013;68:1197-208

16. Smith M, Wilkinson S. Essays Biochem. ER homeostasis and autophagy 2017;61:625-35.

17. Kim JH, Kang HM, Yu SB, Song JM, Kim CH, Kim BJ, et al. Cytoprotective effect of flavonoid-induced autophagy on bisphosphonate mediated cell death in osteoblast. J Cell Biochem 2018;119:5571-80.

18. World Health Organisation. Assessment of Fracture Risk and Its Application to Screening for Postmenopausal Osteoporosis. 1994. WHO Technical Report Series 843, WHO, Geneva.

19. Schleinitz D, Distefano JK, Kovacs P. Targeted SNP genotyping using the TaqMan ${ }^{\circledR}$ assay. Methods Mol Biol 2011;700:77-87.

20. Kroemer G. Autophagy: a druggable process that is deregulated in aging and human disease. J Clin Invest 2015;125:1-4.

21. Zhang $\mathrm{H}$, Baehrecke EH. Eaten alive: novel insights into autophagy from multicellular model systems. Trends Cell Biol 2015;25:37687.

22. Pyo JO, Nah J, Jung YK. Molecules and their functions in autophagy. Exp Mol Med 2012;44:73-80.

23. Li RF, Chen G, Ren JG, Zhang W, Wu ZX, Liu B, et al. The adaptor protein p62 is involved in RANKL-induced autophagy and osteoclastogenesis. J Histochem Cytochem 2014;62:879-88.
24. Chung $Y H$, Jang $Y$, Choi $B$, Song $D H$, Lee EJ, Kim SM, et al. Beclin-1 is required for RANKL-induced osteoclast differentiation. J Cell Physiol 2014;229:1963-71.

25. Sarparanta J, Garcia-Macia M, Singh R. Autophagy and mitochondria in obesity and type 2 diabetes. Curr Diabetes Rev 2017;13;352-69.

26. Kimmelman AC, White E. Autophagy and tumor metabolism. Cell Metab 2017:25:1037-43.

27. Zhou Z, Austin GL, Young LEA, Johnson LA, Sun R. Mitochondrial metabolism in major neurological diseases. Cells 2018;7:229.

28. Revuelta M, Matheu A. Autophagy in stem cell aging. Aging Cell 2017; 16:912-5.

29. Pierrefite-Carle V, Santucci-Darmanin S, Breuil V, Camuzard O, Carle GF. Autophagy in bone: self-eating to stay in balance. Ageing Res Rev 2015;24:206-17.

30. Luo D, Ren H, Li T, Lian K, Lin D. Rapamycin reduces severity of senile osteoporosis by activating osteocyte autophagy. Osteoporos Int 2016;27:1093-101.

31. Onal $M$, Piemontese $M$, Xiong J, Wang $Y$, Han $L$, Ye $S$, et al. Suppression of autophagy in osteocytes mimics skeletal aging. J Biol Chem 2013;288:17432-40.

32. Yang $Y H$, Chen $K$, Li B, Chen JW, Zheng XF, Wang YR, et al. Estradiol inhibits osteoblast apoptosis via promotion of autophagy through the ER-ERK-mTOR pathway. Apoptosis 2013;18:1363-75.

33. Hocking LJ, Whitehouse $\mathrm{C}$, Helfrich MH. Autophagy: a new player in skeletal maintenance? J Bone Miner Res 2012;27:1439-47.

34. Zhao Y, Chen G, Zhang W, Xu N, Zhu JY, Jia J, et al. Autophagy regulates hypoxia-induced osteoclastogenesis through the HIF1alpha/BNIP3 signaling pathway. J Cell Physiol 2012;227:639-48.

35. Lin NY, Chen CW, Kagwiria R, Liang R, Beyer C, Distler A, et al. Inactivation of autophagy ameliorates glucocorticoid-induced and ovariectomy-induced bone loss. Ann Rheum Dis 2016;75:120310.

36. Rachner TD, Khosla S, Hofbauer LC. Osteoporosis: now and the future. Lancet 2011;377:1276-87.

37. Hubbard VM, Valdor R, Macian F, Cuervo AM. Selective autophagy in the maintenance of cellular homeostasis in aging organisms. Biogerontology 2012;13:21-35.

38. Cuervo AM. Autophagy and aging: the importance of maintaining "clean" cells. Autophagy 2005;1:131-140.

39. Umeno J, Asano K, Matsushita T, Matsumoto T, Kiyohara Y, lida $M$, et al. Meta-analysis of published studies identified eight additional common susceptibility loci for Crohn's disease and ulcerative colitis. Inflamm Bowel Dis 2011;17:2407-15.

40. Palomino-Morales RJ, Oliver J, Gómez-García M, López-Nevot MA, Rodrigo L, Nieto A, et al. Association of ATG16L1 and IRGM genes polymorphisms with inflammatory bowel disease: a metaanalysis approach. Genes Immun 2009;10:356-64.

41. Douroudis K, Kingo K, Traks T, Rätsep R, Silm H, Vasar E, et al. ATG16L1 gene polymorphisms are associated with palmoplantar pustulosis. Hum Immunol 2011;72:613-5.

42. Alirezaei M, Fox HS, Flynn CT, Moore CS, Hebb AL, Frausto RF, et al. Elevated ATG5 expression in autoimmune demyelination and multiple sclerosis. Autophagy 2009;5:152-8.

43. Zhu L, Wang H, Wu Y, He Z, Qin Y, Shen Q. The Autophagy Level Is Increased in the Synovial Tissues of Patients with Active Rheumatoid Arthritis and Is Correlated with Disease Severity. Mediators Inflamm 2017:7623145.

44. Nikseresht M, Shahverdi M, Dehghani M, Abidi H, Mahmoudi R, Ghalamfarsa G, et al. Association of single nucleotide autophagy-related protein 5 gene polymorphism rs2245214 with susceptibility to non-small cell lung cancer. J Cell Biochem. 2018 Sep 22. doi: 10.1002/jcb.27467. [Epub ahead of print].

45. Usategui-Martín R, García-Aparicio J, Corral-Gudino L, CaleroPaniagua I, Del Pino-Montes J, González Sarmiento R. Polymorphisms in autophagy genes are associated with paget disease of bone. PLoS One 2015;10:e0128984. 